\title{
Improving Learning Activities and Abilities Write Data Description Through Models Problem Solving Learning in Class VII Students in SMP Negeri 24 OKU
}

\author{
Nurhayati $^{\left.1^{*}\right)}$, Missriani ${ }^{2}$, Yessi Fitriani ${ }^{2}$ \\ ${ }^{1}$ SMP Negeri $24 O K U$, South of Sumatra, Indonesia \\ ${ }^{2}$ Universitas PGRI Palembang, Indonesia \\ ${ }^{*}$ Corresponding author. Email: selamatnurhayati@gmail.com
}

\begin{abstract}
The aim of this study is to identify and describe the increase in learning activities and the ability to write descriptive essays through the Grade VII student problem-solving learning model at SMP Negeri 24 OKU. The aim of this research was to study 27 students in class VII-A. Data collection techniques are observation and testing. The results of this study concluded: (1) There was an increase in learning activities through problem-solving learning models in class VII students at SMP Negeri 24 OKU, and (2) There is an increase in the ability of SMP Negeri 24 OKU students to write descriptive essays through a problem-solving learning model in class VII.
\end{abstract}

Keywords: Learning Activities, Writing Ability, Problem Solving

\section{INTRODUCTION}

Writing as a language skill is recognized by the general public. Writing is an ability that creates a specific command of the language. Writing up is an advanced skill in language learning. Semi [1] argues that writing teaching is the basis for writing skills.

Writing as a language skill requires the expertise of someone to use written language for communication purposes. Therefore, writing skills must involve a variety of skills, namely: (1) the ability to express ideas or ideas; (2) the ability to organize such ideas or ideas; (3) the ability to apply grammatical and syntactic patterns, and (4) the choice of skills structure and vocabulary.

Suparno [2] argues that the writing process is carried out by taking seven steps, i.e. (1) selecting and determining subjects, (2) collecting information, (3) setting goals, (4) writing planning, (5) writing, (6) editing (revision) and (7) writing the finished script.

Writing activities are one of the most recent manifestations of language skills and skills mastered in language learning after listening, reading and speaking [1]. In the same book, it is also explained that, compared to other language skills, the ability to write is more difficult for language learners to master, because writing skills require mastery of different aspects outside of language in order to produce coherent and coherent paragraphs or discourses.

Essentially, the main function of language is as a means of communication. The learning of Indonesian language and literature is therefore directed so that students have the ability to communicate, both oral and written. Learning Indonesian Language and Literature must be directed towards the essence of Indonesian Language and Literature as a means of communication. As it is known that language learning is now changing, from the emphasis on learning the form to learning aspects that emphasize the function aspects. Generally, reading information can have an impact on increasing knowledge and skills.

The activity of writing descriptions, which is a writing competence that already exists and begins at elementary school level, is one of the activities of writing. Descriptive essay allows teachers to sharpen and sharpen students' ability to explain things clearly [3]. Students' can express their feelings, ideas, and ideas to others through the writing of descriptions. The ability to write descriptive essays cannot be mastered automatically by students, but must go through a lot of practice and regular practice to make it easier for students to express themselves in writing. In this connection, the ability to write descriptions must be 
improved since childhood or from elementary school education. If writing skills are not improved, the ability of the student to express thoughts or ideas through writing will decrease or not develop.

As the findings of researchers in daily teaching in the Indonesian language learning process at SMP Negeri 24 OKU for the 2020/2021 school year, in particular class VII-A students in the learning process of writing descriptive essays. For learning components that have been compiled for 6 (six) months (prosema), the syllabus and the lesson plan (RPP) are used, while other subjects must also be provided. This results in a less than optimal ability to write student descriptions. The learning process of writing descriptions is based solely on a conventional approach, so that students who participate in the learning process become monotonous. It has been shown that writing student descriptions that have achieved mastery is as many as 9 students $(33.33 \%)$ while 18 students $(66.67 \%)$ have not achieved mastery.

The researcher examines that there are several factors that cause the ability to write descriptions of students who do not master in learning, namely as follows: 1) the material for writing descriptions that is given only once a month is not optimal and it is certainly difficult for students to understand; 2) students are less interested in writing material descriptions, because material with the same pattern and method (not varied) is always provided; 3) more assignments are given to students, as additional materials must also be provided to maximize the learning process, and 4. Learning to provide students with written descriptions is done using the conventional method. Students would have a positive outlook towards change in order to boost the progress of the country and the state.

As explained above, the researcher sees the problem-solving learning model as one of the learning models that is considered appropriate for increasing the learning activities and writing descriptions of seventh grade students at SMP Negeri 24 OKU.

According to Trianto [4], the problem-solving learning model is a presentation of subjects that exposes students to problems that need to be resolved or resolved in order to achieve learning objectives. Furthermore, Hamdani argues that problem-solving learning is a teaching and learning activity that requires students to be able to find solutions to problems ranging from problems in groups and individuals.

According to Djamarah [5], the following explains the advantages of a problem-solving learning model: 1) this problem of solving the learning model can make school education more relevant to life, especially to the world of work; 2) The process of teaching and learning through problem-solving can accustom students to skillfully confront and solve problems, and this is a very meaningful ability for human life, and 3) Learning to solve this problem model stimulates the development of students' thinking skills creatively and thoroughly since, in the course of learning, learners carry out a number of coherent processes by highlighting problems from different angles in order to find solutions. Teachers need a revolution in learning technology such as e-learning to increase the effectiveness and efficiency of the teaching and learning process in schools [7]. To improve the quality of education services must be supported by competent school principals, educational staff who carry out teaching and learning activities namely teachers, reliable administrative administration, adequate infrastructure and community participation [8]

Based on the background description above, this research focuses on the study of increasing learning activities and the ability to write descriptive essays through a problem-solving learning model for 7 students at SMP Negeri $24 \mathrm{OKU}$.

\section{METHODS}

This research has been conducted in two cycles with indicators of success guidelines, and corrective action will be taken in the next cycle if it is not met. Data collection techniques are methods that researchers can use to collect data. According to Asrori [6], the procedure for each step, there are four stages: (1) preparation, (2) intervention, (3) observation, (4) reflection (reflection). On the basis of these views, the data collection methods used in this analysis were written experiments and observations. Observation data analysis techniques are used to measure student activities during the learning process. The observation sheet consists of three observed indicators, namely as follows. Observation data analysis techniques are used to measure student activities during the learning process.

The test in this study was performed by the researcher on each cycle, both the first cycle and the next cycle, to determine the ability to write descriptions of seventh grade students at SMP Negeri 24 OKU through a problem-solving learning model. The study is a set of questions or exercises of another method used to assess information, intellect, abilities or talents taken by individuals (students) or classes." [9].

The test data analysis technique used the following formula in this study:

(1) the researcher shall use the following formula to assess the writing of the student's essay description of the subject:

$$
\bar{X}=\frac{\sum f x}{\sum n} \times 100
$$


Note:

$$
\begin{array}{ll}
\bar{X} & =\text { Average value } \\
\sum f x & =\text { Overall score frequency } \\
\sum n & =\text { The number of students }
\end{array}
$$

(2) summing up the test results from the learning process

The results of the ability to write essays of student descriptions obtained through the problem-solving learning model of each research cycle using the completeness formula of the student learning outcomes are as follows:

$\%($ complete $)=\frac{\sum \text { students } w \text { hocompleted }}{\sum \text { students }} \times 100 \%$

If complete classical learning has been achieved, action is no longer needed. However, if the results achieved through the actions given will be re-treated in such a way that the increase in learning activities and the ability to write descriptions of seventh grade students at SMP Negeri $24 \mathrm{OKU}$ is consistent with the KKM standards set.

\section{RESULTS AND DISCUSSION}

\section{1) Cycle 1}

Based on the results of the research findings on the action of increasing learning activities and the ability to write descriptive essays through a problem-solving learning model in Class VII students at SMP Negeri 24 OKU in Cycle 1, the results were 1783 with an average of 55.72. The students who achieved mastery learning with $\mathrm{KKM}>67$ were 16 students or the average percentage of completeness was $59.26 \%$.

This means that the ability to write descriptive essays through a problem-solving learning model in class VII students at SMP Negeri 24 OKU in cycle 1 has not yet achieved mastery learning. Not all students can digest and absorb this learning, it is likely that students are not interested in the material presented, namely "My Pride School Environment" to participate in the learning process, and it is also likely that students are lazy to participate in the learning process.

\section{2) Cycle 2}

Based on the results of the research findings on the action of increasing learning activities and the ability to write descriptive essays through a problem-solving learning model in Class VII students at SMP Negeri 24 OKU in Cycle 2, the results were 1859 with an average of 68,85 . The students who achieved mastery with
$\mathrm{KKM}>67$ were 20 students or an average percentage of completeness of $74.07 \%$.

On the basis of the results achieved, the researcher needs to emphasize more about the implementation of the learning process that will be better conveyed, namely focusing on problem-solving learning models so that the results achieved by writing descriptive essays using problem-solving learning models in class VII students at SMP Negeri 24 OKU are more.

\section{3) Cycle 3}

Based on the findings of the research findings on the action of increasing learning activities and the ability to write descriptive essays through a problem-solving learning model in class VII students at SMP Negeri 24 OKU in cycle 3 , the results obtained were 74.93 on average in 2023. The students who achieved mastery with KKM $>67$ were 26 students or the average percentage of completeness was $96.30 \%$.

Writing as a language skill is recognized by the general public. Writing is an advanced skill in language learning. Semi [1] argues that writing teaching is the basis for writing skills. It is therefore clear here that reading is very beneficial to the improvement of one's intellectual, manner and character. Another opinion argues that reading is a process that is carried out and used by readers to get a message that the writer wants to convey through word or written language media [10].

\section{CONCLUSION}

Centered on the findings of the study, it can be concluded as follows: 1) there is an increase in learning activities through a problem-solving learning model in class VII students at SMP Negeri 24 OKU. It is known that in Cycle 1, 13 students participated actively (48.15\%), 8 students participated passively (29.63\%) and 6 people did not participate $(22.22 \%)$. There was an increase in student activity in Cycle 2. As many as 19 people (70.37 per cent) were actively involved, 5 people $(18.52 \%)$ were actively involved and 3 people were not actively involved (11.11\%). In addition, in Cycle 3 there was a further increase, i.e. an active participation of as many as 26 people $(96.30 \%)$, a passive participation of 1 student $(3.70 \%)$ while not participating, and 2) there was an increase in the ability to write descriptive essays through a Grade VII student problem-solving learning model at SMP Negeri 24 OKU. The results of the study showed that the complete cycle of 1 student was 16 students or that the average percentage of completeness was $59.26 \%$. In Cycle 2, 20 students completed the course, or the average percentage of completeness was $74.07 \%$. In Cycle 3 there were 26 students who have passed the test, or on average, percentage of completeness was $96.30 \%$. 


\section{AUTHORS' CONTRIBUTION}

Nurhayati: designed and performed experiments and analysed data. Missriani and Yessi Fitriani: review, translate and proofreading.

\section{ACKNOWLEDGMENTS}

Our deepest gratitude goes to Chancellor of Palembang PGRI University, Director of the Postgraduate Program of PGRI Palembang University and the Education Management Study Program of PGRI Palembang University, who have supported us in doing this extraordinary thing. This project is funded independently. We also want to thank our Education Management friends who helped us a lot in a short time frame to complete this project.

\section{REFERENCES}

[1] Semi. (2014). Dasar-Dasar Keterampilan Menulis[Basics of Writing Skills.]. Bandung: Angkasa.

[2] Suparno \& Yunus, M. (2017). Keterampilan Dasar Menulis [Basic Writing Skills]. Jakarta: Universitas Terbuka.

[3] Novelti., Kristiawan, M., Erpidawati. (2019). Development of the Descriptive Writing Learning Model using the Audio Visual Media. International Journal of Recent Technology and Engineering, Volume-8 Issue-3, September 2019.

[4] Trianto. (2010). Konsep dan Strategi Pembelajaran [Learning Concepts and Strategies]. Jakarta: Rineka Cipta.

[5] Djamarah, S. B. (2012). Belajar dan Pembelajaran. Jakarta: Rineka Cipta.

[6] Asrori, M. (2012). Prosedur Penelitian Tindakan Kelas [Classroom Action Research Procedure] Jakarta: Rineka Cipta.

[7] Rahmadoni, J., Arifnur, A. A., \& Wahyuni, U. M. (2020). Penerapan Schoology Sebagai Learning Management System Bagi Guru SMAN 1 Sutera [Implementation of Schoology as a Learning Management System for Teachers of SMAN 1 Sutera]. Jurnal Hilirisasi IPTEKS volume 3 No 2.

[8] Zulaiha, D., Lian, B., \& Mulyadi. (2020). The Effect of Principal's Competence and Community Participation on the Quality of Educational Services. Journal of Social Work and Science Education Volume 1 (1) E-ISSN: 2723-6919.

[9] Arikunto, S. (2010). Prosedur Penelitian Suatu Pendekatan Praktek [Research Procedure A Practice Approach]. Jakarta: Rineka Cipta.
[10] Rahim, F. (2017). Pengajaran Membaca di Sekolah Dasar dan Menengah [Teaching Reading in Primary and Secondary Schools]. Jakarta: Bumi Aksara. 